\title{
Correction to: Exosomal miR-126 blocks the development of non-small cell lung cancer through the inhibition of ITGA6
}

\author{
Mingjun Li ${ }^{*} \mathbb{D}$, Qianqian Wang, Xiaofei Zhang, Ningning Yan and Xingya Li
}

\section{Correction to: Cancer Cell Int (2020) 20:574} https://doi.org/10.1186/s12935-020-01653-6

Following the publication of the original article [1], the authors notified us that one of the primer sequences in the article was wrong:

- Incorrect sequences: miR-126, F 5'-TGTGGCTGT TAGGCATGG-3' and $\mathrm{R}$ 5'-AAGACTCAGGCC CAGGC-3'

- Corrected sequences: miR-126, F 5'-CGCGTCGTA CCGTGAGTAAT-3' and R 5'-AGTGCAGGGTCC GAGGTATT-3'

The original article has been corrected.

Published online: 02 June 2021

\section{Reference}

1. Li M, Wang Q, Zhang X, Yan N, Li X. Exosomal miR-126 blocks the development of non-small cell lung cancer through the inhibition of ITGA6. Cancer Cell Int. 2020;20:574. https://doi.org/10.1186/s12935-020-01653-6.

\section{Publisher's Note}

Springer Nature remains neutral with regard to jurisdictional claims in published maps and institutional affiliations.

The original article can be found online at https://doi.org/10.1186/s12935020-01653-6.

*Correspondence: didilmj4505@126.com

Department of Oncology, The First Affiliated Hospital of Zhengzhou

University, No. 1 East Jianshe Road, Zhengzhou 450052, Henan, China

(C) The Author(s) 2021. This article is licensed under a Creative Commons Attribution 4.0 International License, which permits use, sharing, adaptation, distribution and reproduction in any medium or format, as long as you give appropriate credit to the original author(s) and the source, provide a link to the Creative Commons licence, and indicate if changes were made. The images or other third party material in this article are included in the article's Creative Commons licence, unless indicated otherwise in a credit line to the material. If material is not included in the article's Creative Commons licence and your intended use is not permitted by statutory regulation or exceeds the permitted use, you will need to obtain permission directly from the copyright holder. To view a copy of this licence, visit http://creativeco mmons.org/licenses/by/4.0/. The Creative Commons Public Domain Dedication waiver (http://creativecommons.org/publicdomain/ zero/1.0/) applies to the data made available in this article, unless otherwise stated in a credit line to the data. 